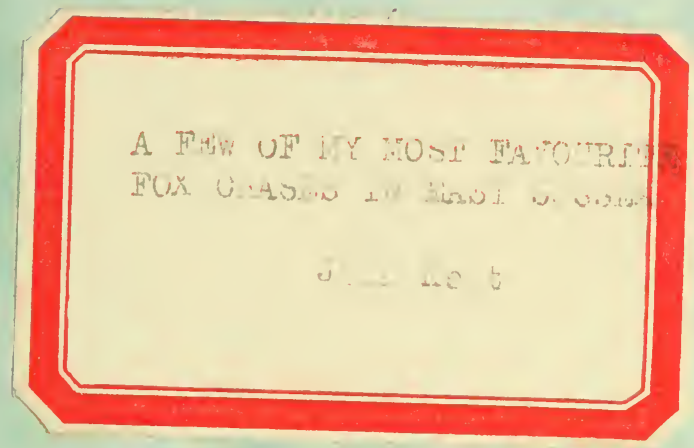




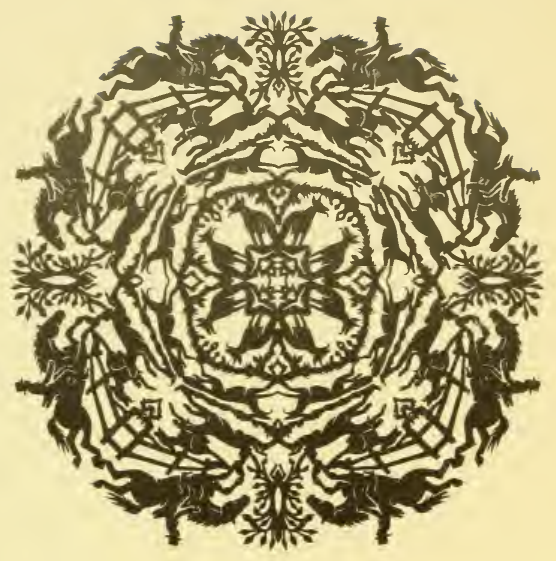

JOHN A.SEAVERNS 


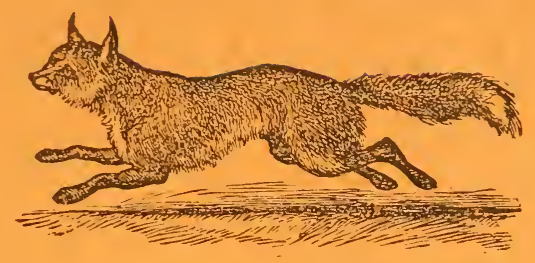

\title{
A FEW OF MY
}

\author{
MOST FAVOURI'TE
}

\section{FOX CII S E S}

\section{IN EAST SUSSEX.}

\author{
B y J OH N K E N T, \\ of Suuthease.
}

PRINTED FOR PRIVATE CIRCULATION. 



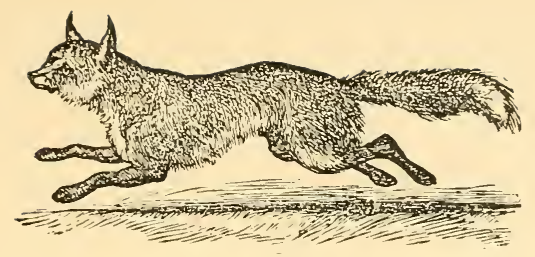

\title{
A FEW OF MY
}

MOST FAVOURITE

\section{FOX CHASES}

IN EAST SUSSEX.

\author{
B r J O H N K E T, \\ of Suuthease.
}

PRINTED FOR PRIVATE CIRCULATION. 



\section{INTRODUCTION.}

Mr. Craver became master of the East Sussex Fox Hounds in the year 1827 and managed them till 1837, (ten years). Colonel CATor had managed them six years previously, having taken them from Mr. King Sampson, and having established the East Sussex Hunt and Country. Captain Green took them from Mr. Craven and managed them six years, when they were laid down. Mr. King Sampsox then came forward and hunted the country with his pack for one season, and then gave up in the year 1844, in consequence of ill health.

From my early youth I always had an ardent taste to hunt and kill the Fox, the only wild animal of the kind that is a great depredator in our land. Often at the meeting of the hounds, great complaints have been made of the Fox making sad havoc amongst the poultry in some neighbouring farm yard; and these are my pleasures in drawing for him; see the hounds drag him through the bushes, and in the thick briars unkennel him; have at him my good hounds, he is a rogue, he has robbed my neighbour, pursue him with all vengeance, and kill him. These are my feelings in hunting the Fox; I love to see him fight and die. 



\section{FOX CHASES.}

Few. 10, 1824.- On Thursday, the East Sussex Fox Hounds met at Plumpton l'lain ; they threw off at Mr. Laine's furze, where they soon found a fox, he broke covert into Stammer Park, going down Mr. Moon's side, and completely ringing the park, coming out within a few rods where he went in; he then crossed Mr. Moon's hill, a complete burst by Broad Shackles to Boxholt Bottom ; here we came to a check for a few minutes. Perkins held them round and hit him off, we then went down the four-mile course into Ashcombe plantation, crossing the road, and climbing Kingstone hill by the sheep ponds, crossing Kingstone and Swanborough hill, round Iford hill, in front of Balsdean by Hervey's Stone and Pickers Hill Barn, (here Major Cater exclaimed, "gentlemen, take care of your horses"). We then went orer Highdoole and Telscombe Tye, crossing the Warren and Great Hoddern Farms, to the cliff near the pay-gate, where we came to a check; and a check it was, for but a very few horses could go on again. It was quite a scene to see the gentlemen dismounted, some slacking their girths, others holding their heads round to the wind, some poking the handle of their whips in their mouths to give them all the air they could, and others walking and leading their horses on homewards; but now Perkins held back for the short head and hit off the scent; we went on over Piddinghoe and Newhaven hills into Bullens Bush, here reynard was staying, but broke covert immediately, and away we went down the deep fallow into Waterman's Bottom, (here the Doctor's old grey mare pitched on her head, a most awful fall), and across the Great Hoddern Farm by Heathy Brow, to Telscombe Tye, over Highdool, and down Northease Hill, up by the Fore Hill Bushes to the front hill; but now there were only about seven horses, and they were going one by one, no two together, and the hounds were more than a mile ahead. I got to the top of Iford hill and stood and looked on, Perkins was nearest the hounds, on what I called "old Staring Tom," but his name was Mr. Merriman; he was obliged to get off and lead him, and could not make him go so fast as he could run, which made him say queer words. They went down across the fallows between Swanborough and Kingstone, by the brick-yard, and over by the six-sweep mill; here Perkins hailed a gentleman in the turnpike to stop the hounds, which he did, Perkius blowing his horn, got them away, and took them home. This was a most tremendous day, every horse in the field was dead beaten, the chase must have been more than thirty miles; no one fox could have stood this drilling. I am quite satisfied we changed our fox in Boxholt 
Bottom, a fresh fox must have stolen away out of the scrub-bushes, and Perkins drew on the line, as another fox was seen to go over the hill for Wallingore. At the pull up on the cliff, Major Cater was one to walk and lead his horse homewards over Southease Bridge to Beddingham, where he put him up at Mr. Todd's, because he could not get him any further, and there he died ; the Major was the one to tell us to take care of our horses but did not think of his own. The Doctor's old grey mare pitched on the fallow a most tremendous fall. The Doctor got up and shrugged his shoulders, and found himself not much hurt; he then paid all attention to the mare, she struggled and groaned, and at last appeared to be quite dead: the Doctor exclaimed, "what a fool I have been to ride my mare to death, I would not have taken 150 guineas for her." The old mare groaned again, but she soon appeared lifeless; the Doctor lifted up her head, but it fell dead; he opened her eyelash, and looked at her eye, and it appeared dead. The Doctor now got in a rage, and said "only to think that I should be such a d-fool to ride my mare to death, when I would not have taken 150 guineas for her?" he stamped, and swumg his whip, and said all sorts of queer words. One gentleman who was stopping to assist, thought he saw life in the old mare; he applied his whip thong to her, when the old mare groaned, struggled, and got up on her legs. The Doctor said, " now I must go to Brighton ;" he mounted, and rode off with the old white mare and himself both well rolled in the sellow clay.

March 1, 1827.-On Thursday last, the East Sussex Fox Hounds met at Laughton Pound, and very shortly unkemnelled a fox in the neighbourhood. Reynard went off in gallant style at a splitting rate, taking through Laughton Levels. The rapidity of his motion, and the difficult route he had chosen, left many of the sportsmen at a very humble distance from his brush ; many indeed, who were not punctual to the hour of appointment, lost the opportunity of adjoining the chase at all. Learing the Levels of Laughton, he made towards Chiddingly, thence to Warbleton, after which he directed his course to Waldron, and onward through Heathfield to Brightling, where he was headed; he then shaped his course towards Burwash, close to which town the clogs ran into him, and he was killed in gallant style, after the most severe rum that had been experienced during the season. The wipper-in received an ugly fall, his horse having plunged with him into the middle of one of the deep dykes; with some difficulty, however, he extricated both himself and his horse, and again joined the chase, and was, notwithstanding the accident, in at the death, an honour which only himself, one sportsman (George Berry), and the huntsman could boast of.

On Saturday the same hounds met at Plumpton, and after drawing Wallingore wood unsuccessfully, they crossed the river at Barcombe Mill, and proceeded to the Plashett Park, near to which, in a piece of gorse, they found. The fox went off in capital style, and produced a most excellent run; he however ultimately evaded his pursuers near Short Gate. Many of the sportsmen, owing to the heavy state of the country, experienced some severe falls; but the only accident 
of a serious nature, that we have heard of, befel Mr. Foley, who had the misfortune to dislocate one of his shoulders.

Ferreary 22, 1830.-On Monday the East Sussex Fox Hounds met at the Swan, Chailey, they drew the coverts, the south side of the turnpike to the North Common, blank; then crossed the turnpike by the King's Head, and drew all the Newiek great coverts a blank. At half-past two o' elock the hounds were thrown into Baldneth wood, opposite the Swan, when at twenty minutes to three, upon the grassy bank, the voice of "Old Griper" pronounced he had unkemnelled the vermin; "hoi! Griper, have at him" said Hemmesey, and have at him they did in good truth, the scent was a merry one, the fox was bold, and broke covert immediately aeross the enelosures for Newick Old Park; the hounds were all together and well at him, and away they went; through these great coverts they rattled him, erossing the road by Longford through these little woods, and then into Bareombe brooks we dashed, erossing the river a little above the Anchor bridge, which was handy for us to go over; the brooks on the opposite side were nearly all mider water. Some rode into the ditehes, and some ont, happy was he that was lueky, and now on for the Plashett; up through this great covert they pushed him, and were gone away a field a head when we got to the top of the wood, and on for Cromp's furze field, which they threaded, and this let a batch of the leading horses have a fair start with them; now through the enclosmres, leaving Horsted to the left, on, and by Mount Ephraim. Here was fox hunting in all its splendour, the hounds runuing at a rapid pace, topping the hedges three or four couple abreast, and we were obliged to top them too or stop behind-there was no looking for places, but every one obliged to cut out his own line. Captain Croft got an ugly fall and obliged to relinquish the chase. He now bent his line by Framfield Street, as if for Buxted, when on a little eommon among some sheep we eame to a eheek of three minutes, a lucky one for Mr. Craven, for his horse was in the ditch and just time to get him out again, when Hennesey drew the hounds on the line and away we went again; he now verged his line to the right, and erossed the turnpike near Blackboys, in a line for Barnet wood, but ere he reached that, going up some little meadows the hounds threw up and were casting, when the fox slipped out of the hedge-row behind them, down the meadow, and was met by a puppy named "Justice ; " here was a regular battle between the fox and "Justice," sometimes one had the best of it and sometimes the other, but now the whole pack had cast baek into the field and saw what was going on, came and put an end to this fine chase at halfpast four o'elock, through a heavy eountry, in one hour and fifty minutes, only thirteen horses came in at the death. Mr. Lane exclaimed " this is the finest chase I ever saw in Sussex;" for my own part it was the favourite chase of my life, the hounds were never off the scent only the three minutes on the common, and the horses were in a gallop the whole chase ; it was a trial of strength, nothing but a strong and well-seasoned horse, and a good fencer could go through it, (ah, and though I say it, with a pretty good 
rider on his back.) Mount Ephraim was a poser which tailed them off and made the field select. It was a brilliant chase. Press said the line we run was twenty miles; if so, I rode more than fifty miles this day.

March 6, 1830.-On Saturday, the East Sussex Fox Hounds met at the back of the wall, at the north end of Lord Chichester's park; it was a fine gay morning, and a field of a hundred and twenty horses. At eleven o'clock the hounds were thrown off in Standean furze, at the side hill, and in a few minutes the voice of old "Jovial" pronounced the traitor nigh. Hoi! "Jovial" has him said Heunesey; the fox broke covert immediately into the valley below, in a straight line for Clayton Holt; the hounds were out immediately after him, and away they went with a breast high scent, "Ruin" and "Rosamond" taking the lead ; the field was now in a great confusion, every one making his best way in shifting the deep bottoms to get to Clayton Holt; but when the leading batch of horses got here, the hounds were gone through and sinking into the valley below, and now on for Clayton woods, and throngh these coverts they slicked him, and by Damny they dashed into Randol's copse; here reynard ranged the covert and brought the hounds to hunting. Now we crossed the turmpike near the pay-gate, and went on through Wick wood at a smart hunting pace, from thence to Woodmancote, and here we came to a check, and rery near to a fatal one, for the sun shone bright, and the fallows were dry and dusty, the hounds were drawn across the line but they could not tonch it, but little "Wonderful," a puppy, straggling along behind, pinned her nose down to the scent and cherriped merrily, but she could not hunt it a yard, the old hounds were brought to see if it was good, which they owned, but they could not hit it off; this gave Hennesey the point, and he trotted on across two or three large fallow fields and held them round, and "Jovial" was the hound to hit him off again ; we went on then for some miles at a slow hunting pace, what I called a loosing one, we left Henfield to the right, and got nearer to the brooks ; the scent improved, the hounds began to get merry, and into the brooks we went, now the hounds stretched their length, and we began to go some in the ditches, and some out, the hounds crossed the river below MIotesbridge; the water was low, some attempted to ride through, but nearly got mired in the mud, most of us cut round over the bridge, and luckily we got a cut in with the hounds again, as they were ruming very fast, evidently close at their fox. The leaps now were numerous, and falls plentiful, here Mr. Strange got an ugly one, which broke his collar bone. We now crossed the turmpike near Partridge Green, and then came out on Jolesfield common, the hounds were rumning and carrying a head as if on the open down, but all at once they threw up; the fox had made a short head, the hounds cast back and hit hin off over into a little garden, in front of a brick cottage ; here reynard had crouched himself down in one corner, but the houmds unkennelled him, and out on the open common they came in full view, round the faggot stacks they ran, over the hedge into the brick-yard, and into the 
pond he bolted, the hounds killing him in the cold bath; he was then taken out on the common, and thrown down to the hounds; there were about fifty horses in at the death, and I think I never saw a lot of men better pleased. It was a splendid chase of 25 miles in two hours and ten minutes, the first part of the chase from the find to Randel's copse, was a tiptop thing, not a horse could live with them ; the middle part, the huntsman and the hounds had the greatest difficulty in making out the line; but the latter part, the hounds ran gloriously into their fox. In returning home, Mr. Wood and a friend from Lewes, were climbing Ditchling Bosthill, when Mr. Wood's horse signified he would rather go down the hill than go further up; after some consultation, it was agreed, and with some difficulty he was taken back to Ditchling, and after the short space of three weeks he was enabled to walk home to Lewes.

January 19, 1832.-On Thursday, the East Sussex Fox Hounds met at Newtimber Imn; a foggy day. There was a good field of sporting fellows, and we all made up our minds to ride and keep the hounds in view. The hounds were thrown off in the holly bed below, found immediately, and away we went through the Wick wood, and then I camnot tell where, but some who knew the country, said we were near Henfield; here the fox headed, and we came back the side wind, but where, I camnot tell : the scent was a pleasing one, what I call kept us alive, with plenty of leaping, but all at once the hounds appeared to me to be going right up into the air. "Halloa, George," said I to the huntsman, "where now ?" he replied, "I think we are going up the front hill ; " "what front hill"" said I, he said, "he thought it was Folking." We got to the top, and managed to keep the hounds in view, across the wheel ruts we blundered, and sunk into the bottoms below, but I do not know where, but I think it was near Portslade; we went on, and then came to a large furze covert, and Press said he knew where we were, this was Herringham furze,-this we skirted round; after this, we rode up hill, down hill and side hills, and then right into a chalkpit, (not over mind ye), on enquiry we found this was one of the Beading chalk-pits : here reynard got into a hole, and we could not get him out. It was a beautifnl hunting run of two hours, and only one check of about three minutes ; some thought we had had a very good day's sport, and wished to go home, others thought they should like to taste a little more of the fog. Mr. Craven wished to please all, and said he would draw a little covert below Hedberton on the road home. The hounds were taken to it, and a beautiful little furze covert it was ; the hounds were thrown in, and in quick time the musical voice of old Jovial gave the chimes for starting, and a start it was-the fox broke covert immediately right under the horses bellies, and the hounds were out as quickly, after him ; away we went into some little brooks below, some in the ditches and some out; the hounds soon told us we must mend our pace from the last chase, or we should not long have them in view,--through the Wick wood we went again, and a long way straight north, but I do not know where ; the chase was kept up at a desperate pace, leaps were numerous, 
and falls plentiful. The fox now headed, and came back, leaving Henfield to the right, the hounds were close at him, horses were getting tired, and falls at almost every fence, and here, among the rest, your humble servant got one, in leaping over a hedge and ditch into an old muddy lane; the old mare pitched on her head, and of course, I pitched on mine; the mare got up first, but she stopped for me; I was quickly up and mounted again, but I was obliged to scrape the mud out of my eyes before I could see anything. The next leap we came to was over a hedge and ditch sinking into a fallow field; friend Kettel was the first to have it, and the first to get a fall, and his horse rolled right over him, but like a Britain, he was soon up and mounted again, and quickly had the hounds in view; we kept labouring on, and now some gentlemen said here is Wood's mill, but one gentleman was not quite satisfied with this information, he rode slap into the mill pond,-never mind, he got out again, he only made a hole in the water, and it was all done to keep the hounds in view,--but of course we could not stop, we kept galloping on, and dash into Truly furze field we came ; here reynard was dead beaten, but that was of no use, the hounds could not get hold of him, he kept getting back on his foil ; we were here a long time, at last he bolted into 'Totington wood, which was just by, and that was full of foxes; it was half-past four o'clock, and getting dark; Mr. Craven ordered the hounds to be stopped; we run that slapping chase, which lasted one hour, without a check, and our horses were all sadly beaten. I now set the old mare's head in a direct line for Southease, as I had something like the tune of 20 miles to ride home. In riding across Truly sands, I saw a gentleman in scarlet sitting under the hedge, smoking a cigar, and his horse in the ditch beside him. I said " halloa, sir, what ce n't you get him out?" He replied, "Oh, yes, I can get him out Kent, but the poor devil is tired, and so am I, let him rest a little, and he will get out ; " this was F. Thomas, Esq. I then rode on and got into the road, and when I came to Folking there was a pool of water, and as my head and face was covered with mud, I thought I should like to rinse some of it off. I called at the cottage just by, and asked the old lady to lend me a dry cloth, which she did. I gave my head a good sousing in the water, and then rubbed myself dry with the cloth, which made me quite comfortable. I carried the cloth back to the old lady, I thanked her, and gave her a trifle to wash the cloth again ; she said, "she did not think I had got a face when I came for the cloth, but I see you have now, sir." I now mounted and rode on again. I was soon overtaken by Mr. Ingram; he was highly delighted with the fine day's sport we had had, and also with his young four-year old horse, in carrying him so well. We rode together to the old dog kennel at Brighton, and then I turned off for Falmer, it was very dark and foggy; when I came to the foot of Newmarket hill I thought I could find my road over the foot-path to Kingstone, but I soon got lost in the fog. I knew where I was all the time as Pat said, I knew what 20 acre fallow I was on, but what use was that, I could not get off. I kept riding and riding, but I could not get off the piece. I rode for an hour, at last I came 
to a steep bank, I knew the bank, and knew the foot-path was in the bottom below. I got off and walked, and found the path ; I now made up my mind to walk the path to Kingston. I walked and walked, and at last I walked out into the road at the foot of Newmarket hill, where $I$ came in ; I was now quite satisfied. I mounted, and rode quietly round the road, and got home at nine o'clock. I had been gone just 12 hours, and I think I must have ridden 70 miles this day, as my journey to and from covert was more than 35 miles. I heard no more of the day until the next Tuesday, at Lewes market. I saw Mr. Barchard ; he said, "well Kent, how is the old mare?" I said " she is all right now, I have got her here, but she would not feed until Sunday ;" he replied, " his horse had not eaten anything since, nor more had Mr. Thomas's, and that Sewall, at Brighton, had got 30 horses under him from that day, and that Mr. Ingram's horse had not stood up since, only as he had been slung up; he died in the course of a few days."

Fen. 6, 1834.-The East Sussex Fox Hounds met on Thursday last at Horsted Alms House, and drew the Horsted covers a blank ; they then tried the Plashett l'ark, where they unkemnelled a gallant fox, which broke corer in the finest possible style ; the hounds were elose at him, and went off at a splitting pace, crossing the Broyle on to Broyle-place; he then took a straight line to General Trevor's decoy, at Glynde, and crossed the River towards Glynde mill ; thence on to Firle, threading the pleasure grounds of Lord Gage; he then proceeded on mder the hill, leaving Compton Wood and Tilton shaw to the left. Reynard now climbed the front hill, near to White Bosthill, and took to the open downs, crossing the Firle hills, on to Denton Hill, and thence on to Norton Top, and Bletchington Down ; he then took the Sutton hedgerow, and, finally, to Chinton, where the hounds ran into him, and killed in most beautiful style, after a chase of one hour and fifty minutes. The distance from the Plashett to the pleasure grounds of Lord Gage, was performed in fifty minutes, and in the humting phrase, produced bellows to mend. This was one of the most splendid rums ever experienced in Sussex, and the day will be long remembered by the sportsmen who were in the field upon the oceasion. Mr. Thomas Johnson's and the huntsman's horses both died from this chase.

Fenruary 10, 1836.-On Wednesday, the East Sussex Fox Hounds met at Norton Top; after drawing several coverts blank, they drew Mr. Dray's covert in France bottom, where they unkennelled a fine fox, which broke covert immediately ; the homds were out quickly after him, and went off at a topping pace up the hill, crossing the fallow for Hindover, but here the hounds threw up, and cast right and left in good order, but they could not hit him off. Press now came forward to do the trick for them; he took them off the fallow, and held them round a nice sweet gratten, but it was no go; he then dropped back on the turf for the short head, he made the draw complete, but he could not touch the line; he was now staggered, and said he must be gone forward, he would hold on towards the 
hedge-rows. Mr. Craven and myself were riding along together down beside the fallows, when I dropped my eye on reynard crouched down in one of the furrows. Ah ! Charley, thought I to myself, what, you are there, are you ; the old fox-hunter had a little inward feeling; now that was rather pleasing, to think he could give the alarm at any minute to please a whole field of fox-hunters,--but the way to please folks is, to let them get a good appetite, and then feed them, it is sure to relish and please,- -but now things were getting very flat and dull, scarcely a word to be heard in the field, the horses getting shivery with cold; now, thinks I to myself, is the time to ring the bell for starting. I said to Mr. Craven, " if you want to see your fox, I can show him you ;" he replied, "what do you mean, Kent?" I said, "if you wish to see your fox, come with me, and I will show him to you ;" he said, "by gad, it is the very thing I want to see," with the fox-hunting courage flying into his eyes. He now exclaimed alond, "Kent is going to show me our fox ;" this ran through the field like lightning, and the tables were quite turned, all merry and gay. I now put the old mare in a canter, as I know when you raise the courage of a fox-hunter, he likes to go on; he cannot bear to be stopped. I got to the furrow and pointed out the fox, some said it was not; Mr. Craven rode up the furrow, and soon saw it was the fox ; he then blew his horn for the hounds, as Press knew nothing of this. At the sound of the horn reynard bolted, the hounds were quickly on the scent, and away we went, the devil to pay, blundering into the deep bottom, and then climbing the hill to Hindover; here he headed to the right, straight up Cradel hill to Norton-top at a racing pace, and on to the top of MIr. Geere's hill ; he now headed short to the left, down across Denton lames, leaving the barn to the right, and Norton to the left, climbing the steep hill, and then bending to the right down across Denton south lane, and into the brooks they dashed. Up to this point, about five miles, reynard had run with the wind in his teeth, the pace was tremendous, there was a string of horses for a mile distant ; but now he headed, and took the down wind, up through Heighton village, over the old dencher, Heighton hill, and on to white Bosthill chalk pits, where we lost him ; time, 55 minutes. Immediately he sunk the wind, the hounds could not hold the scent, and the pace was very slow; in the up-wind burst, Mr. T. Ellman and Mr. MIonk, both mounted on thorough-breds, took the lead as if riding a race, or as we foxhunters say, to see which was top-sawyer; at all events, they both had an opportunity to go their best pace, which I believe they did, for Mr. Monk's horse died in a few days after, when of course Mr. Ellman had the chirrup, as his horse was all right, but I understood he could not get out of the stable for something like a fortnight, but this I will not vouch for.

East Sussex Fox Hounds, January 16, 1837.-On Monday last the above Hounds met at Laughton Pound, at their usual time, and threw off in Laughton Great wood, where, at half-past eleven, they unkennelled as stout a fox as ever ran before hounds. Rejnard seemed quite alive to the trick; he was not to be dodged or twisted 
but set his head straight, and went off in the finest possible style ;the hounds were altogether, and close at home:-the scent was breast-high, and they slicked him through this great covert in quick time and "gone away." The field was all confusion and bustle, every one seeming to predict something severe:-the route taken was leaving Easthothly to the right, and Whyly to the left, straight to Barnett Wood, and on erossing the Blackboys turnpike road, leaving Dalrymple's to the right on to near to the town of Mayfield; here the wily rogue still finding himself hard pressed, took a circle to the left, crossing Hadlow Down back to Framfield; again to the left, and worked himself to Barnett Wood, taking nearly his foil again crossing Blackboy's tumpike and leaving Dalrymple's to the left, then crossing over the Mayfield tumpike on to the Cross-inhand Fair field, to the Herrings;--thence to Heathfield, nearly to the town of Burwash, then heading back, to Broomham, where the hounds ran in to him, and killed in the finest style, after a most laborious task of six hours duration.-Mr. Craven not being out, the huntsman had no one to assist him ; but great merit is due to Press for the skill he exhibited, and the strength of mind he displayed in persevering; nothing else could have killed this strong fox. The field was sadly beaten off long before the death, and not a horse conld go on, with the exception of the huntsman's, and he had had quite enough of it.--The fleet and young hounds, which took the lively part of the chase in the first twelve miles, now began to get slack, and the fox had lost his speed, changing his point and commencing the shifting system. Nothing but hunting would now avail, and the old hounds were called upon to do their duty, which they performed in the most admirable style.- The huntsman did not return home to the kemmel until ten o'clock at night.

Splendid Run with the East Sussex Fox Hounds, Nov. 17, 1838. -On Friday, the 17th instant, the East Sussex Fox Hounds met at Southease. ("A Bye-day.") After drawing several coverts blank, they drew Northease link bushes; they had been in covert but a short time before a hound began to whimper-this had not been repeated thrice before a bold fox made his appearance, and went off in " gallant style ; " being a foggy day, the huntsman would not allow his hounds to go on till he had got them all out of covert; this being done he drew them across the line of scent, and they went off with a crack, over Iford-hill, leaving Hervey's stone to the left, dipping Ballsdean deep bottom, and over the hill by the direction post, in a straight line to Fielder's furze, threading them to the left over Hodshrove hill, crossing the Lewes road, near to Hodshrove, climbing the steep hill by the barn, to Hollingbury Castle, on the Withdean plantation, Patcham-mill, erossing the London road leaving Pateham village to the right, taking the hedgerow in a straight line over the hill, crossing the Dyke-road by Blatchington-hill; bere reynard erossed this road at twenty-one minutes past one o'clock, the hounds at twenty-tive minutes past, the fox therefore having four minutes the advantage !! He then took a straight line to the Dyke furze; up to this point he had run 
the side wind, but now he began to shift, and took the down wind; at this period our informant's horse was beaten to stand still, and he saw no more of the run, but immediately afterwards the clouds lowered upon the field, as if lamenting the loss of one of the best sportsmen from this excellent chase, and in the end, shed tears in good earnest, which washed away the little scent there was left, and gave the fox time to secrete, and we hope, recover himself in Portslade.

JAN. 12, 1839.-On Saturday, the East Sussex Fox Hounds met at the Rainbow; after drawing some small coverts blank, they drew Wallingore wood, where they unkenmelled a fine strong fox, which broke cover in good style towards the hills, and through Mr. Cripps' plantation down the road to the chalkpit, where reynard got into the drain under the road, but he was soon unkennelled again, and the hounds drew on the scent, when he took to the Downs, crossing Plumpton and Mr. Moon's hills, leaving the upper plantation to the right, taking a line to the back of Ditchling Bosthill; here he headed and went straight to the bottom near Standean, making a short head again to the right, crossing the green flats and climbing the steep hill, leaving Clayton Holt to the right, then on to Clayton windmill, where he headed short to the left, leaving Pangdean Holts to the right, dipping the green bottom in a line for Patcham, but making a circle over the hill to the right to Pangdean hill, where the hounds ran into him in view. It was a most excellent chase with a lively scent, but the zig zag line made it very difficult to keep the pack together; at the short head in the bottom, near Standean, the body of the hounds and the leading horses were thrown on the back ground, as two couples of hounds which were covering the right wing caught the scent and went off with it such a pace, that the pack could not be got well together until they came to the head of Clayton mill, when they assembled again, and the huntsman hallowed " hold hard, gentlemen, a minute, let me hold them round," when he exclaimed, "Hoi, neighbours, hit him off ; my good hound," and away they went the remainder of the chase at a most clipping pace, and ran into him in full view, killing in fine style.

Nov. 11, 1813.- On Monday, the East Sussex Fox Hounds met at Abbot's Wood. The spirited master and Press, with a good sprinkle of pink, accompanied by about thirty other sportsmen, seemed to predict and " entertain a sort of inward feeling" there was something good in store for them. The morning too was just what sportsmen like-without either sun or wind. It was truly a$$
\text { "- Delightful scene, }
$$

Where all around was gay, men, horses, hounds, And in each smiling countenance appeared Fresh blooming health and universal joy."
}

The business-like looking pack were taken from the meet to Ludley coppice; scarcely were they all in cover ere old Druid proclaimed Pug was on foot, he broke on the North side, and made for Chalvington and Ripe, leaving the mill to the right-took direct across the 
enclosures to the Lullums, and ran through that beautiful grass country to Laughton-place; the pace being good, ditches rife and plentiful as blackberries in June, soon rendered the field select, and the scene somewhat amusing. Men and horses on the opposite sides of ditches-some in-others pulling and whipping-lots craningone thorough-bred black nag, well covered with pink, being the only one who cleared the reach and lived with the hounds. The upper end of Glynde road did not alter his line, crossing it he passed on to Moor Lane, near to Hailsham turnpike road, leaving Ringmer barracks, and the old East Sussex Kennel to the right-ran through Sir James Langham's plantations, up the side hanging coverts in front of the house to the top of Glynde Hill.

\footnotetext{
" What lengths we pass; where will the wand'ring chase Lead us bewilder'd! Look back and view The strange confusion of the vale below Where sour vexation reigns ;-

* * * * old age lanents

His vigour spent; the tall, plump, brawney youth

Curses his cumbrous hulk, and envies now

The short pygmean race he whilome kenn'd,

With proud insulting leer. A chosen few Alone the sport enjoy, nor droop beneath Their pleasing toils."
}

Boldly facing the open downs by Oxtittle bottom, he ran on to the corner of the enclosure on Cliffe Hill ; being headed by some one coming out of the town he turned short to the right across the Coombe, and into Mr. Hillman's Stoneham chalk pit; four couple of the hounds went right over, and had a most awful fall. He now took to the vale again by crossing the Ringmer turnpike-road, passing Stoneham House, Wellingham, the Uckfield turnpike-road, and into the brooks at lower Stoneham, there gallantly swam the Lewes river into the Hamsey brooks; old Druid was soon on the opposite bank, and having acknowledged the line was instantly joined by all his bold compeers. Not so with the field. Glynde road had been crossed, but this was a poser. Barcombe mills were soon sought for ; passing the church ran Coneyborough Park on to Cooksbridge; he then crossed sheffield turnpike. Warningore being close to the left, and faced Chailey South Common, where he got into a side drain. Press was shortly at hand, and in a few minutes he was again made to fly; but all his whiles were vain and strength exhausted, the gallant pack ran into him, and honest John's whohoop was music to the happy [few] fellows present.-This run forcibly reminds us of the doings of the East Sussex Fox Hounds in Mr. C.'s palmy days ; may they return again. Should their spirited veteran owner meet with the encouragement such persererance richly deserves, they most assuredly will. The hounds are much improved in appearance since last I saw them, and have received a great addition in a few couples of chase hounds from other kennels.

Мarch 8th, 1844.-On Friday, King Sampson's Fox Hounds met at Telscombe Tye; they threw off at Banning's, Mr. W. Saxby's favourite fox covert, where old "Drewid" soon told us there was a 
fox handy, but they drew the corert a blank; then they drew Mr. Beard's covert just by, when there was a halloa gone away for Telscombe Tye; the hounds were quickly taken to the scent, and they soon told us it was a spicey one, but the foot people had headed him about, and the hounds were as wild as willicks. Press held them on to the straight line when they all settled together, laid down their sterns, and away they went at a most tremendous pace across Telscombe old lands, over Church furlong, and into Crocksdean bottom, climbing to the top of Southease hill, dipping into the cricketting bottom like lightning, up Mr. C. Saxby's hill, over Highdool, and by Northease link bushes; now they dipped into the Iford green flats, "Gossip and Governess" taking the lead, as if coupled together, over the sweet brows, and through the green flats they went, at a most rapid pace; now climbing to the top of Iford hill, taking the side coombs in front of Iford, Swanborough and Kingston, coming up by the sheep ponds, and dipping into the awful cold coombs, crossing the deep bottom below ; now climbing again, leaving Newmarket plantation to the left, circling round this sweet turf for the top of Falmer sheep down, but ere he could reach that, the fleet hounds were pressing fast upon him; he verged his line, sunk the hill, and bolted into Falmer great ploughed lane; here the hounds soon got view of him, and it was a complete course all down this great lane into the hedge beside the turmpike, crossing the tumpike, and back into the hedge again; what with the cracking of the hedge, the shrill chirrup of the hounds, and every one of the field that was up, throwing a little of their dog language, made the place quite in an uproar; but reynard beat them all like a game fox, out into the road he came, bolting up the cutting for Falmer village a view, but here he could reach that, the hounds ran into him, and put an end to this splendid chase. The excitement of the fox-hunter was raised to the highest pitch, men scarcely seeming to know what to say to each other; the horses were sobbing and panting, you might look round and see horses coming over the hills for two miles back; the distance was eight miles in the open, through a very hilly country, but all on turf, except Falmer ploughed lane ; time, 37 minutes. I cannot say too much in praise of this excellent chase ; it was admitted by all to be the most complete thing from beginning to end (taking the distance) they ever saw, it was a complete race with the hounds, but the ladies had it, and they always will; give me the lady pack, they touch and go on, while the dogs are thinking about it; horses had no chance to live with them. Mr. Monk, on his beautiful grey, singled himself out by riding away from the whole field.

As this staunch little pack is now to be laid down in consequence of the venerable owner having numbered the years of three-score and ten, and his health not being good enough to follow his hounds, it cannot be expected he can keep them for the amusement of others. For my own part, as a fox-hunter for this, and many other good days sport I have had with his hounds, I most sincerely thank him; more so as he was the first to establish a pack of fox hounds in East Sussex, and the last to lay them down. 
As a pack of fox hounds in East Sussex is now quite extinct, to those who read my pamphlet, I must bid adieu; there are no more of those meetings where you see one of the finest packs of hounds, some of the noblest of the horse kind, and some of the greatest nobles and gentlemen of our land, all meeting together,-who can deny but this was a delightful scene. I much regret to lose sight of the scarlet coat, that beautiful scarlet coat is now no more to be seen, but is now turned to the bottled green. Only just take a little piece of scarlet, about the size of a gentleman's coat sleeve, hang it round a lady's shoulder, and see what a beautiful bloom it will put on her cheek.

Brooksme Harriers, Jax. 11, 1836.-In consequence of the snow on the ground on Monday last, these harriers did not go to their meeting place [Newmarket Hill], but threw off at Rodmell, where they found an old sporting hare at the back of the village. She took away to North-bank, through Southease village, up the lanes crossing Southease Sheep-down to the Hodden Heathy Brow, from thence to Bearshide-gap, along the cliff to Portobello to Bannings and Rodmell Heathy-brow; here she headed, and skirted the back of Telscombe village across the Old Lands, down Hockham Bottom, taking the Old Road at the back of Deans, and on to Southease Stump Bottom; -here she got up in view, and the hounds went of course at the top of their speed by Notch Bushes through the Cricketting Bottom, crossing Rodmell and Northease hills, dipping the Iford Green Flats, touching Swanburgh Hill, the hounds still running at a rapid pace, with Liberty and Newsman taking the lead; she then skirted the side hill in front of Balsdean, and on to Harveys Stone, where the pack ran into her and killed in fine style. This was the best run these harriers have had during the season, or, perhaps, for many seasons before. The field was much beaten and the cold iron was frequently tried on, but many of the steeds could not answer the demands and it was not without difficulty that others arrived at the killing point. Owing to the inclement weather, the field was but small, but those who were there will long remember the day. This was a famous old sporting hare, which had been hunted for several seasons before by the same pack, but never could be overtaken. She was named the Old Court-barn Hare, in consequence of her always being to be found on the land called the Court-barn Lands, belonging to Mr. C. Saxby, who jocosely used to say to the huntsman, "Ah, you cannot kill my old Court-barn hare," but alas! the time was come for poor Puss to die-the pack with triumphant voices seeming to proclaim "the victory is ours."

Charley . Wilkins's Fox Chase.-Being on a visit at a friend's and out of my own county, he invited me to have a day's hunt with the fox hounds, as they would meet within a few miles of his residence the next day. I had been much used to road riding, but not in a chase, and thought I should like to see them ; but neither I nor my horse, I thought, would be able to follow them. My friend said, "I have two good hunters, and as you have never seen a fox chase 
you shall have the best horse, and I hope you will raise your courage and do justice to him; he will earry you through the country well up to the hounds." We then took another glass or two of wine, and agreed it should be so, and went to bed in high spirits for the chase the next day. The next morning, up, breakfast and all right, morning beautiful, and the meeting place at Mount Pleasant; my friend was all alive. "Come Charley," said he, "on with your spurs; let us get there in good time, as you have never seen a pack of fox hounds meet. I wish you to see eversthing to-day." "Bring the horses out Dick." We mounted, and off we started for Mount Pleasant; distance, five miles. "All in good time Charley, we will take it easy." We had not gone far before we overtook the hounds. My friend seemed to know every person we came near, and every one seemed to know him. "Well, Harry," said he to the huntsman, " what, you have got the lady pack to-day." "Yes, sir," replied the huntsman, "the hounds are in beautiful trim," and, added Harry, they are "pretty well up to the mark. I think they only want to find a good one, and they will show you the way." This lady pack amused me very much, for there were two whippers-in ; and every now and then a hound was inclined to stray away from the others, and they were sharply rated by one of these whips, and called by their names, such as Ladybird, Laundress, Adelaide, Abigirl, Winifred, Rosamond, Rachel, Gertrude, Ganymede, \&e. They might well be called the lady pack, for their beantiful, yet different colours, their neatly turned shapes and the graceful manner in which they mored about; indeed their pride seemed as if the ground was searcely good enough for them to go on. I could not but admire them-I was delighted to see them. We were now arrived at the meeting place, Mount Pleasant. Here it was pleasing to see the sportsmen coming in all direetions, and the gentlemen with their top boots, white buckskin breeches and scarlet coats; as neat as if they had come out of a bandbox and their steeds equally neat. About 100 were now at the "meet," the huntsman then moved on by order of the master of the hounds to draw the covert at the side hill, about half a mile distant. The hounds were taken steadily to the covert, and by some signal, which I could not perceive they in an instant all dashed in. The huntsman immediately leaped the fence with thein, and the two whips cantered off to different stations; each seemed to know the route. The huntsman began to cheer his hounds by "Yoak, Joak, drag him, joak, wind him." 'They had been in eovert but a short time, before one of the hounds began to whimper, "Yoak, drag him my good bitch, he is not far off, I warrant it," said the huntsman. Very shortly after another hound chirupped louder, "hoike to Barmaid, have at him old bitch, that will do ; elewhoyke, elewhorke, have at him my good hounds," continued he, with a rattling twang from the horn. The hounds now soon got together and began to make the covert echo. The fox made his appearance at one side of the covert, but was headed by the horsemen. He then ringed the covert and the huntsman halloaed "stand away gentlemen; clear away; don't jou see the fox making the same point again. Get away that gentleman on 
the white horse;" this was quickly attended to. "Tally-ho" roared out a great ploughman at the bottom of a field. "Yonder he goes down beside the hedge row," gone away with a view hollow from the field. The huntsman now soon made his appearance out of covert, with a sound of the horn. The hounds were slipping out in all directions; the huntsman walking his horse steadily on, not towards the line of scent. This I perceive was to get the body of his pack together; one hound was straggling down beside the covert towards the scent and the whips neither being up, the huntsman bawled out "stop that liound, stop that hound you on the cock tail horve. D-n that cad, he is asleep." The huntsman now put the hounds on the line of scent, and went off in beautiful style, trking into the lowlands some beautiful large green meadows with simong rough fences ; they call them "bullfinchers." My horse was res dy for anything. I came near, but I was very nervous, for sometimes I was on his neck, and then back again on the saddle, but I begun to see several falls, which put me a little in better spirits ; thinking I was not the worst rider; when just to my right hand down came a big gentlemen on a black horse, such a "gruffer;" this made me feel at little queer again. We now soon came to a fence again. I think they called it a "rasper ;" my horse took it in fine style, but by jingo in settling I went over his head such a double-up. I at first thought I was killed, but I found myself on my legs rumning after my horse ; fortumately for me a kind gentleman caught the rein of my horse's bridle with the handle of his whip, and I soon mounted again. We then came to smaller inclosures, but luckily for me the gates were open, and I rode through them (but mind you the hounds were a little getting a head of me now.) We then came to a large wood with a wide brook to leap over; I was not afraid of water so much as I was of the rough fences, so that I charged this quickly, but my horse stopped short, and I went over his head into the ditch-a very umpleasant situation I can assure you ; it was a little muddy too; as well as wet, and discoloured my white "smalls." I was now on one side of the ditch, and my horse on the other side; but a man a hedging seeing my situation ran and caught my horse and brought him to me, and turned him over the ditch. I then mounted again, giving the man half a crown. I said "I was in a pretty pickle." He replied, "that is nothing at all, sir, two gentlemen got in, horses and all, ten times worse mess than you are, down at the other end of the wood." He added "if I went through the wood a little way, I should come into a ride, and that would bring me out of the gate into an old lane ; there I should be sure to see something of the hounds, for I had quite lost them." Going along this old lane, I saw a man up in a high tree. He said, "you are got behind sir." I replied "yes, I am ; can you see the hounds." He answered "yes; they are two miles ahead ; they are going over Batchelor's high fields, beating away to the common ; if you ride a good pace you will get there in time with the hounds." In riding along this old lane a crow boy the other side of the hedge halloaed "war bog, war bog, sir." "War bog," said I, "what do you mean." (Why sir, if you ride right along there 
you will go plump into that there bog, and you will want one of our master's cart horses to draw your horse out but if you rides clos: to that hedge there is no bog at all." "Thank you my lad." " Bog, ah ! I have heard talk of bogs ; I don't want to get in those places; I have had bog enough to day," thought I. Well, all at once I came out on the common; there I saw a lot of foot people rumning out of a brickyard halloaing "tallyho." "Well" said I. "Right through the breaks there, Sir." "I see him," but these brickmaker chans began to laugh one to the other, saying "he has had a summerset at any rate." Another said, "he has been christened and no mistake " I looked to my left, and there I saw the hounds coming through the breaks. I was now well up again, and all on an open common, where we ran him through heath and breaks for full two miles, and to my delight without a fence to jump, and ran into him in the open. "Who whoop" was the halloa, "Who whoop :" the huntsman took the fox from the hounds, and laid him on a hawthorn bush, cut the head, brush, \&c., off, the hounds baying him at the time. He then threw him to the hounds, and they devoured him most eagerly. My friend now recognised me again. "Ah, Charley, my boy" said he, "I am glad to see you in at the death; beautiful run; splendid Chase ; one hour and forty minutes," [delightful said I] " but you have had a summerset I see; you are not alone; lots of falls to-day, Chailey." My attention was now drawn to the field to see the contrast between the meet at Mount Pleasant and the "kill" on the common; only about forty gentlemen were in at the death, and they were all bedaubed and splashed with mud; and the hounds were not like the same animals; they were so bedraggled and spattered over. We got off the common on the turmpike; lit our cigars; and rode steadily home, joking and talking orer the different scenes of the day.

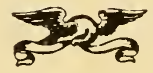




